\title{
Biological and chemical assessment of zinc ageing in field soils
}

Article

Accepted Version

Donner, E., Broos, K., Heemsbergen, D., Warne, M. S. J., McLaughlin, M.J., Hodson, M. E. and Nortcliff, S. (2010) Biological and chemical assessment of zinc ageing in field soils. Environmental Pollution, 158 (1). pp. 339-345. ISSN 0269-7491 doi: https://doi.org/10.1016/j.envpol.2009.06.034 Available at https://centaur.reading.ac.uk/1693/

It is advisable to refer to the publisher's version if you intend to cite from the work. See Guidance on citing.

To link to this article DOI: http://dx.doi.org/10.1016/j.envpol.2009.06.034

Publisher: Elsevier

All outputs in CentAUR are protected by Intellectual Property Rights law, including copyright law. Copyright and IPR is retained by the creators or other copyright holders. Terms and conditions for use of this material are defined in the End User Agreement.

\section{www.reading.ac.uk/centaur}

\section{CentAUR}

Central Archive at the University of Reading 
Reading's research outputs online 
Running head: Biological and chemical assessment of zinc ageing in field soils.

\section{Corresponding author:}

Erica Donner

Urban Pollution Research Centre

Middlesex University

Hendon Campus

The Burroughs

London, NW4 4BT

United Kingdom.

Tel. +44 (0)20 84116583

Fax: +44 (0)20 84116774

Email: e.donner@mdx.ac.uk 
Biological and chemical assessment of zinc ageing in field soils

Erica Donner ${ }^{\dagger *}$, Kris Broos ${ }^{\S a}$, Diane Heemsbergen ${ }^{\S}$, Michael St. J. Warne ${ }^{\S}$, Mike J. McLaughlin $^{\S} \|$, Mark E. Hodson ${ }^{\dagger}$, Stephen Nortcliff ${ }^{\dagger}$.

${ }^{\dagger}$ Department of Soil Science, The University of Reading, Whiteknights, Reading RG6 6DW, United Kingdom.

$\$$ Current address: Urban Pollution Research Centre, Middlesex University, Hendon Campus, The Burroughs, London NW4 4BT, United Kingdom.

${ }^{\S}$ Centre for Environmental Contaminants Research, CSIRO Land and Water, PMB 2, Glen Osmond, South Australia 5064, Australia.

" School of Earth and Environmental Sciences, University of Adelaide, PMB 1, Glen Osmond, South Australia 5064, Australia

${ }^{\text {a }}$ Current address: VITO - Flemish Institute for Technological Research, Boeretang 200, 2400 Mol, Belgium.

*To whom correspondence may be addressed (e.donner@mdx.ac.uk). 


\begin{abstract}
As zinc $(\mathrm{Zn})$ is both an essential trace element and potential toxicant, the effects of $\mathrm{Zn}$ fixation in soil are of practical significance. Soil samples from four field sites amended with $\mathrm{ZnSO}_{4}$ were used to investigate ageing of soluble $\mathrm{Zn}$ under field conditions over a 2-year period. Lability of $\mathrm{Zn}$ measured using ${ }^{65} \mathrm{Zn}$ radioisotope dilution showed a significant decrease over time and hence evidence of $\mathrm{Zn}$ fixation in three of the four soils. However, $0.01 \mathrm{M} \mathrm{CaCl}_{2}$ extractions and toxicity measurements using a genetically modified lux-marked bacterial biosensor did not indicate a decrease in soluble/bioavailable $\mathrm{Zn}$ over time. This was attributed to the strong regulatory effect of abiotic properties such as $\mathrm{pH}$ on these latter measurements. These results also showed that $\mathrm{Zn}$ ageing occurred immediately after $\mathrm{Zn}$ spiking, emphasising the need to incubate freshly-spiked soils before ecotoxicity assessments.
\end{abstract}

Capsule: Ageing effects were detected in $\mathrm{Zn}$-amended field soils using ${ }^{65} \mathrm{Zn}$ radioisotope dilution as a measure of lability, but not with either $\mathrm{CaCl}_{2}$ extractions or a lux-marked bacterial biosensor.

Key words - attenuation; aging; isotopic dilution; lability; lux biosensor 


\section{INTRODUCTION}

Zinc $(\mathrm{Zn})$ is an essential trace element, ubiquitous in soils, and fundamental to the healthy functioning of biological systems. It is also a potential toxicant when present at elevated concentrations. Consequently, the dynamics of $\mathrm{Zn}$ in soils are of widespread interest, both in relation to crop nutrient deficiencies and associated impacts on farm yield and economy (Brown et al., 1993; Alloway, 2003) and in terms of soil health and toxicity (McLaughlin et al., 2000; Warne et al., 2008a). The distribution, mobility and bioavailability of $\mathrm{Zn}$ in soils is controlled by a range of physico-chemical characteristics, including the nature and heterogeneity of the soil constituents, the surface charge of soil colloids, and variations in soil $\mathrm{pH}$ and redox status. This paper focuses on the sorption and fixation of $\mathrm{Zn}$ in a range of soils with differing physicochemical characteristics. The general term 'sorption' is used throughout, due to the difficulties in differentiating between adsorption and precipitation under common experimental conditions (Sposito, 1984).

Previous research investigating the kinetics of soluble metal sorption in soils has shown that the process can essentially be divided into two steps, with an initial stage of relatively rapid sorption followed by a secondary stage that can continue over weeks, months or even years (Barrow, 1986; Smolders and Degryse, 2007). Furthermore, studies investigating metal desorption and/or chemical extractability have typically shown considerable hysteresis, with a negative correlation between desorption/extractability and the residence time of the metal in the soil (Barrow, 1986; Sparks, 1998). This gradual, ongoing process of sorption and fixation has become known as 'ageing' or 'natural attenuation'. Greater understanding of ageing could aid in the modelling and prediction of long-term changes in metal lability and bioavailability. This would be useful for environmental risk assessment and decision making (e.g. in 
relation to 'safe' metal loading rates) and could also enable land managers to maximise the benefits following application of trace metal fertilisers to land.

Although there is substantial evidence of Zn ageing in soils (e.g. Barrow, 1986; Ma and Uren, 1997a and 1997b; Tye et al., 2003; Degryse et al., 2004), the mechanisms and soil properties controlling this are only superficially understood, and much of the evidence comes from laboratory studies conducted under controlled conditions, leaving considerable uncertainty as to the kinetics and practical significance of ageing in the field. In order to understand the implications of ageing for environmental management and risk assessment this knowledge gap must be addressed, for although variations in soil properties and experimental conditions in field studies can mask effects and make data interpretation difficult, the confirmation of hypotheses under field conditions is strongly indicative of a meaningful effect. To elucidate the practical consequences of metal fixation there is also a need for more research using biological endpoints to measure the effects of ageing. To date, most of the research investigating ageing reactions in the toxic concentration range has taken a chemocentric approach, prompting Lombi et al. (2007) to highlight the importance of integrated biological and chemical assessment in revealing both the mechanisms and the effects of metal ageing.

The experiment reported in this paper used soil samples from four Australian field trials, each with a wide range of $\mathrm{Zn}$ loadings as $\mathrm{ZnSO}_{4}$, to investigate the ageing of soluble $\mathrm{Zn}$ under field conditions over a two-year period. Both chemical and biological based assessments were used to investigate $\mathrm{Zn}$ ageing, including: $0.01 \mathrm{M} \mathrm{CaCl}_{2}$ extractions; isotopic dilution with ${ }^{65} \mathrm{Zn}$ ( $\mathrm{E}_{\mathrm{a}}$ - and $\mathrm{E}_{\mathrm{e}}$-values); and the acute toxicity response of a genetically modified lux-marked bacterial biosensor (Escherichia coli HB101 pUCD607). Lux biosensors present a novel approach for investigating the 
effects of $\mathrm{Zn}$ ageing, and this study is one of the first to use the method for this application (see Paton et al., 1997 for further information on the use of microbial biosensors for soil toxicity testing). The use of the lux-biosensor to measure changes in acute toxicity has a major advantage over more traditional microbial ecotoxicity endpoints (e.g. substrate induced respiration or nitrification) as the lux-marked bacteria are not indigenous to the soils and results thus cannot be confounded by adaptation of the soil microbial community.

\section{MATERIALS AND METHODS}

\section{Experimental design, field sites, and field-aged soil samples}

The field trials used in this study were established as part of the Australian National Biosolids Research Program (NBRP), a large-scale research program designed to investigate the potential benefits and risks of recycling biosolids to agricultural land (McLaughlin et al., 2006; Broos et al., 2007; Warne et al., 2008a; Warne et al., 2008b). Metal-salt trials (cadmium $(\mathrm{Cd})$, copper $(\mathrm{Cu})$ and $\mathrm{Zn}$ ) were also established at many of the NBRP field sites and the work presented here used $\mathrm{ZnSO}_{4}$-amended samples from four of these sites, chosen to cover a range of soil properties. Samples that had been spiked ( $11 \mathrm{ZnSO}_{4}$ treatments per site) and aged in the field for up to two years were compared with freshly spiked samples established using 'control' soils from the same four sites. Two field replicates from each $\mathrm{Zn}$ treatment were analysed for the field-aged soils, and two experimental replicates for the matching freshly spiked treatments. Fieldaged samples were collected after the first (T1) and second (T2) crop harvests at each field site. Hence, depending on the site, T1 samples were aged in the field for 7-12 months, and T2 samples for 17-24 months after addition of soluble $\mathrm{Zn}^{2+}$. For a detailed description of the NBRP field trial establishment and subsequent soil sampling, preparation and storage refer to Broos et al. (2007). 


\section{Preparation of the freshly spiked soil samples}

Freshly spiked (T0) samples were prepared in the laboratory using control soils from each of the four field sites to give approximately the same range of $\mathrm{Zn}$ concentrations as were present in the field samples (T1 and T2). For each Zn treatment duplicate $150 \mathrm{~g}$ soil samples were placed in plastic containers. The appropriate aliquot (ranging from 40 $\mu \mathrm{L}$ to $4500 \mu \mathrm{L}$ ) of $\mathrm{ZnSO}_{4}$ stock solution (containing $659.6 \mathrm{~g} \mathrm{ZnSO}_{4} .7 \mathrm{H}_{2} \mathrm{O} \mathrm{L}^{-1}$ ) was diluted with deionised (DI) water to give a spiking solution volume of $30 \mathrm{~mL}$ per sample, then added to the soil and mixed thoroughly by hand. After a 16-hour equilibration period, the samples were leached with several pore volumes of 'Artificial Rain Water' (ARW) containing $10^{-3} \mathrm{M} \mathrm{CaCl}_{2}$ and $5 \times 10^{-4} \mathrm{M} \mathrm{K}_{2} \mathrm{SO}_{4}$ (Broos et al., 2004) until the electrical conductivity (EC) of the leachate was $<2 \mathrm{mS} \mathrm{m}^{-1}$. The leached samples were air-dried at $40{ }^{\circ} \mathrm{C}$ and sieved $(2 \mathrm{~mm})$.

\section{Chemical and physical characterisation of soils}

Soil $\mathrm{pH}$ was measured using 1:5 soil:0.01 $\mathrm{M} \mathrm{CaCl}_{2}$ extracts $\left(\mathrm{pH}_{\mathrm{CaCl} 2}\right)$ and $\mathrm{EC}$ was measured in 1:5 soil:water extracts. Clay content $(<0.002 \mathrm{~mm})$ was determined by the pipette method. Organic carbon (OC) was determined as the difference between total carbon and carbonate carbon, with total carbon concentration measured by ignition with a Leco CNS elemental analyser and carbonate carbon determined by measuring pressure increases after addition of $\mathrm{HCl}$ to the soil in closed containers (Sherrod et al., 2002).

Soil samples $(2.5 \mathrm{~g})$ were extracted for determination of exchangeable cation concentrations and cation exchange capacity (CEC) $\left(1 \mathrm{M} \mathrm{NH}_{4} \mathrm{Cl}, \mathrm{pH} 7.0\right)$ using a mechanical leaching device based on the method of Rayment and Higginson (1992). Samples were analysed for $\mathrm{Ca}^{2+}, \mathrm{Mg}^{2+}, \mathrm{Na}^{+}$and $\mathrm{K}^{+}$using a GBC 906AA Atomic 
Absorption Spectrophotometer, and for $\mathrm{NH}_{4}{ }^{+}$using an Alpkem segmented flow autoanalyser. Pre-treatment to remove carbonates was not required.

The methods used for the determination of dithionite-citrate extractable Fe and acid ammonium oxalate extractable Fe were those of Blakemore et al. (1987). Total Zn and Fe concentrations were determined by aqua regia digestion. Elemental analysis was by inductively coupled plasma - optical emission spectroscopy (Spectroflame Modula ICPOES).

\section{$0.01 \mathrm{M} \mathrm{CaCl}_{2}$ extractions}

For the $0.01 \mathrm{M} \mathrm{CaCl}_{2}$ extractions, $5 \mathrm{~g}$ samples of soil were equilibrated for 16 hours with $25 \mathrm{~mL}$ of $0.01 \mathrm{M} \mathrm{CaCl}_{2}$ on an end-over-end shaker. The samples were then centrifuged at $2200 \mathrm{~g}$ for 15 minutes and an aliquot was used for $\mathrm{pH}$ measurement (completed within 2 hours of extraction). The remaining sample volume was filtered $(0.45 \mu \mathrm{m})$ and acidified to $\mathrm{pH} 1$ with $5 \mathrm{M} \mathrm{HNO}_{3}$, before being analysed for $\mathrm{Zn}$ by ICPOES.

\section{Isotopic dilution with ${ }^{65} \mathrm{Zn}$ (E-values)}

Isotopic dilution with ${ }^{65} \mathrm{Zn}$ was used to monitor changes in the labile $\mathrm{Zn}$ fraction over time. The procedure was based on the method of Young et al. (2000) but $0.1 \mathrm{M} \mathrm{CaCl}_{2}$ was used instead of $0.1 \mathrm{M} \mathrm{Ca}\left(\mathrm{NO}_{3}\right)_{2}$ and all solutions were filtered $(0.45 \mu \mathrm{m})$ before analysis. The activity of the ${ }^{65} \mathrm{Zn}$ spike was adjusted for different soil types $(20$ - $40 \mathrm{kBq}$ ${ }^{65} \mathrm{Zn}$ per sample) to ensure that a suitable gamma-counting rate would be obtained. Analysis of $\mathrm{Zn}$ concentrations in solutions was by ICP-OES and a Wallac 1480 Wizard $^{\mathrm{TM}}$ 3" Automatic Gamma Counter was used for radio-assay. 
The labile or 'isotopically available' $\mathrm{Zn}$ fraction (henceforth referred to as the $\mathrm{E}_{\mathrm{a}}$-value) was calculated using Equation 1 (Hamon et al., 2002a):

$$
E_{a}=\frac{Z n_{\text {sol }}}{Z n *_{s o l}} \times R \times \frac{V}{W}
$$

where $E_{a}$ is the concentration of labile $\mathrm{Zn}$ in the soil $\left(\mathrm{mg} \mathrm{kg}^{-1}\right), Z n_{\text {sol }}$ is the concentration of non-radioactive $\mathrm{Zn}$ in solution $\left(\mathrm{mg} \mathrm{L}^{-1}\right), \mathrm{Zn}^{*}$ sol is the concentration of radioisotope remaining in solution after the $3 \mathrm{~d}$ equilibration time $\left(\mathrm{Bq} \mathrm{mL}^{-1}\right), R$ is the total amount of ${ }^{65} \mathrm{Zn}$ added to the sample $\left(\mathrm{Bq} \mathrm{mL}^{-1}\right), V$ is the solution volume $(\mathrm{L})$ and $W$ is the mass of the soil sample $(\mathrm{kg})$.

All $E_{a}$-values calculated for this experiment were corrected for background $\mathrm{Zn}$ and the lability results are thus expressed in terms of the percentage of total added $\mathrm{Zn}$. This was calculated using Equation 2:

$$
\% E\left(Z n^{\text {added }}\right)=\frac{E_{a}-E_{a}{ }^{\text {control }}}{Z n^{\text {total }}-Z n^{\text {controltotal }}} \times 100
$$

where $E_{a}$ is the sample $E_{a}$-value, $E_{a}{ }^{\text {control }}$ is the mean $E_{a}$-value for the matching control soil, $\mathrm{Zn}^{\text {total }}$ is the total $\mathrm{Zn}$ concentration of the sample, and $\mathrm{Zn}^{\text {control total }}$ is the mean total $\mathrm{Zn}$ concentration for the matching control soil. All values are expressed as $\mathrm{mg} \mathrm{kg}^{-1}$. The 'isotopically exchangeable' $\mathrm{Zn}$ fraction $\left(\mathrm{E}_{\mathrm{e}}-\mathrm{value}\right)$ was also calculated for each sample. This fraction represents $\mathrm{Zn}$ on soil surfaces that is in equilibrium with the soil solution (Hamon et al., 2002b). The $\mathrm{E}_{\mathrm{e}}$-value differs from the $\mathrm{E}_{\mathrm{a}}$-value by excluding the solution $\mathrm{Zn}$ component as shown in Equation 3 (with all terms expressed in $\mathrm{mg} \mathrm{kg}^{-1}$ ). 
$E_{e}=E_{a}-Z n_{s o l}$

[Eqn. 3]

\section{E.coli. HB101 pUCD607 lux biosensor assay}

The lux biosensor was applied as an acute toxicity assay to all samples. The sample solutions used in the assays were 1:1 soil:water extracts (25 g soil: $25 \mathrm{~mL}$ DI water, equilibrated for 4 hours on an end-over-end shaker, centrifuged at $2500 \mathrm{~g}$ for 45 minutes and filtered $(0.45 \mu \mathrm{m}))$. Duplicate $900 \mu \mathrm{L}$ aliquots from each sample solution were transferred into $5 \mathrm{~mL}$ luminometer sample tubes for the bioassay. The remaining solution was divided into 2 subsamples, with one aliquot acidified in preparation for ICP-OES analysis and the other frozen $\left(-19^{\circ} \mathrm{C}\right)$ until analysed for dissolved organic carbon (DOC) using a Scalar Formacs HT TOC Analyser.

Freeze-dried cultures of the E. coli HB101 pUCD607 lux biosensor were obtained from Remedios Ltd., UK. For each assay a vial of $E$. coli was rehydrated with $10 \mathrm{~mL}$ of sterile $0.1 \mathrm{M} \mathrm{KCl}$ whilst gently agitating on an orbital shaker for 60 minutes at $25^{\circ} \mathrm{C}$. Immediately following resuscitation, $100 \mu \mathrm{L}$ of the cell suspension was added at 15 second intervals to each of the $5 \mathrm{~mL}$ sample tubes containing $900 \mu \mathrm{L}$ aliquots of sample solution and mixed by pipette. Each sample was left to stand for exactly 15 minutes before the light output was measured (again at 15-second intervals) on a Junior LB 9509 luminometer (spectral sensitivity range 380-630 nm). The results were recorded in relative light units (RLU). As soon as the bioluminescence measurements were completed, the $\mathrm{pH}$ of the inoculated samples $\left(\mathrm{pH}_{\mathrm{H} 2 \mathrm{O}}\right)$ was measured using a Thermo Orion ROSS 420A+ pH microprobe. 
All sample solutions were measured in duplicate and the mean results used for all further analysis. The lux response for six matching control samples (i.e. no added $\mathrm{Zn}$ ) for each soil type were also measured as part of each assay, and the mean control value was used to convert the measured bioluminescence results from RLU to 'percentage of control luminescence'. This conversion made the results of different assays comparable. The converted results were used to calculate effective concentration $\left(\mathrm{EC}_{\mathrm{x}}\right)$ values and their $95 \%$ confidence intervals (95\% CIs) for each of the soil type/sampling time combinations investigated. The $\mathrm{EC}_{\mathrm{x}}$ of a substance is the concentration that causes a defined magnitude of response $(\mathrm{x})$ in a given system. Biological evidence for a decline in $\mathrm{Zn}$ availability due to ageing would be indicated by increasing $\mathrm{EC}_{\mathrm{x}}$ values (based on the total $\mathrm{Zn}$ concentration) from $\mathrm{T} 0$ to $\mathrm{T} 2$.

Results from anomalously dark sample solutions ( $<2 \%$ of samples) were not included in the $\mathrm{EC}_{50}$ calculations as darker solution colours can cause quenching of the sample luminescence, thereby confounding the results (Ivask et al., 2004). The biosensor results for the Dutson Downs field site were also excluded from analysis and are not presented in this paper as their $\mathrm{pH}_{\mathrm{H} 2 \mathrm{O}}$ values were below the optimum biosensor $\mathrm{pH}$ range (pers. comm., Dr. G. Paton, University of Aberdeen). A preliminary experiment (results not shown) confirmed that $\mathrm{pH}_{\mathrm{H} 2 \mathrm{O}}<5.5$ adversely affected the biosensor.

\section{Statistical analyses}

All statistics were calculated using Microsoft Office Excel and XLStatistics Version 5 (Carr, R., XLent Works, Australia). The significance of ageing effects was tested for each soil type using linear regression analysis between the chemical response variables (i.e. $\mathrm{CaCl}_{2}$-extractable $\mathrm{Zn}$ and $\mathrm{E}_{\mathrm{a}}$-values) and the added $\mathrm{Zn}$ concentration (i.e. measured total concentration of each soil sample minus the average total $\mathrm{Zn}$ concentration of the 
matching control samples). The concentrations of added soil Zn that caused a 50, 20 and $10 \%$ reduction in bioluminescence (i.e. $\mathrm{EC}_{50}, \mathrm{EC}_{20}$ and $\mathrm{EC}_{10}$ ) and their $95 \mathrm{CIs}$ were calculated by fitting a log-logistic distribution according to the method of Barnes et al. (2003). Where $95 \%$ CIs did not overlap they were considered to be significantly different (Barr, 1969; Lo, 1994; Nelson, 1989). However, when 95 \% CIs were overlapping statistical significance can not be inferred (Barr, 1969; Lo, 1994; Nelson, 1989) and the standard error of the difference test (Sprague and Fogels, 1977) was used to test for differences between the $\mathrm{T} 0$ and $\mathrm{T} 2 \mathrm{EC}_{50}$ values. As the number of comparisons was very small and no significant differences were claimed on this basis, Bonferroni adjustment was not applied to these results.

\section{RESULTS AND DISCUSSION}

\section{Characteristic soil properties}

A summary of selected soil properties is given in Table 1. Soil $\mathrm{pH}_{\mathrm{CaCl} 2}$ ranged from 3.9 at Dutson Downs to 6.6 at Spalding. Electrical conductivity (1:5 soil:water extracts) was relatively low, ranging from 0.06 to $0.1 \mathrm{dS} \mathrm{m}^{-1}$. Organic carbon content was $\leq 2 \%$ in all soils except Dutson Downs (5.6\%). Clay content ranged from 4 \% (Dutson Downs) through to $32 \%$ (Kingaroy), and CEC (pH 7) varied from $7.9 \mathrm{cmol}^{+} \mathrm{kg}^{-1}$ (Dutson Downs) to $17.7 \mathrm{cmol}^{+} \mathrm{kg}^{-1}$ (Spalding). Cation exchange sites were dominated by $\mathrm{Ca}^{2+}$ in all soils. Kingaroy, a Ferrosol, was the only soil with substantial Fe content (14.5\% total $\mathrm{Fe})$.

Total $\mathrm{Zn}$ concentrations in the control soils ranged from $11 \mathrm{mg} \mathrm{kg}^{-1}$ (Dutson Downs) to $90 \mathrm{mg} \mathrm{kg}^{-1}$ (Kingaroy) and the total $\mathrm{Zn}$ ranges in the amended samples also varied for different soil types and sampling periods (Table 1). The differences occurred partly because the amendments for each soil type were chosen on the basis of plant toxicity 
data and were thus soil specific (Warne et al., 2008a; Broos et al., 2007), and partly because the T0 samples were not sampled directly from the field plots but were amended (and leached) in the laboratory. Furthermore, the lower total $\mathrm{Zn}$ concentration in the $\mathrm{T} 2$ soils compared with matching treatments in the T1 soils (i.e. earlier samples from the same field plots) suggests that some ongoing leaching, erosion, or dilution by soil mixing occurred between the T1 and T2 sampling periods. However, as measured rather than nominal $\mathrm{Zn}$ concentrations were used for all calculations, the differences in total $\mathrm{Zn}$ concentrations do not complicate the interpretation of results. Total added $\mathrm{Zn}$ (remaining) was calculated for each individual sample by subtracting the mean background total $\mathrm{Zn}$ for the relevant control soil from the total $\mathrm{Zn}$ measured in the sample. This ensured that all ageing results were related directly to the soluble added $\mathrm{Zn}$ rather than the native $\mathrm{Zn}$ already in the soil system, as in contrast to the added $\mathrm{Zn}$, native $\mathrm{Zn}$ would not have been $100 \%$ labile at the start of the experiment.

\section{$0.01 \mathrm{M} \mathrm{CaCl}_{2}$ extractions}

Linear regression analysis of the $0.01 \mathrm{M} \mathrm{CaCl}_{2}$ extractable added $\mathrm{Zn}$ vs. total added $\mathrm{Zn}$ for each soil type and sampling period (Table 2$)\left(\mathrm{R}^{2}\right.$ ranged from 0.79 to $\left.0.99, \mathrm{p}<0.01\right)$ revealed that although the soils showed some significant differences $(\mathrm{p} \leq 0.05)$ in extractability for the investigated time periods, there was no consistent trend of decreasing extractability with time, making it unlikely that any changes in slope were due to ageing. These results are not in keeping with those of previous studies indicating progressive fixation of soluble Zn added to soils (e.g. Boawn et al., 1960; Brown et al., 1964; Follett and Lindsay, 1971; Armour et al., 1989; Tye et al., 2003; Degryse et al., 2003). However, given the large impact that soil properties can have on extractability and metal partitioning, it is possible that the inherent field variability in key properties such as $\mathrm{pH}$ may have complicated and masked trends in these results. Measured $\mathrm{pH}_{\mathrm{CaCl} 2}$ 
values were not consistent across sampling times and treatments, and linear regression analysis comparing the mean control soil $\mathrm{pH}$ for each sampling period and soil type against the slopes of graphs of $\mathrm{CaCl}_{2}$ extractable $\mathrm{Zn}$ vs. total $\mathrm{Zn}$ (not shown) showed significant differences $\left(\mathrm{p}<0.01, \mathrm{R}^{2}=0.86\right.$ ), indicating that the $\mathrm{CaCl}_{2}$ extraction results would be highly affected by any variations in sample $\mathrm{pH}$. It is well established that $\mathrm{pH}$ is a master variable affecting metal partitioning in soil systems (Sauvé et al., 2000; Impellitteri et al., 2001). These findings thus suggest that soil properties may have played a greater role than contact time (i.e. ageing) in determining Zn extractability by $0.01 \mathrm{M} \mathrm{CaCl}_{2}$.

\section{Labile $\mathbf{Z n}\left(\mathbf{E}_{\mathbf{a}}\right.$ values $)$}

There were linear relationships between labile added $\mathrm{Zn}$ and total added $\mathrm{Zn}$ for the different sampling times $\left(\mathrm{R}^{2}\right.$ ranged from 0.98 to $\left.1.00, \mathrm{p}<0.01\right)$ and the decreases in lability over time observed for the Dookie, Kingaroy and Spalding soils (i.e. decreasing slopes for labile vs. total added $\mathrm{Zn}$ regressions) were statistically significant $(\mathrm{p} \leq 0.05)$ (Table 3). For both Kingaroy and Spalding the changes in slope indicated that fixation was more extensive in the early stages of the experiment, with both soils showing a significant decrease in lability from $\mathrm{T} 0$ to $\mathrm{T} 1$, but no significant difference between $\mathrm{T} 1$ and T2. This observation of decreasing fixation over time also concurs with the results of Tye et al. (2003).

Although $\mathrm{pH}$ is also known to affect the lability of added soluble $\mathrm{Zn}$ in soils (Degryse et al., 2004), the $\mathrm{pH}$ dependency of the labile and salt extractable fractions differs (Nakhone and Young, 1993) and small variations in $\mathrm{pH}$ apparently have relatively little effect on $\mathrm{Zn}$ lability at $\mathrm{pH}$ values $<6$ (Tye et al., 2003). As all of the samples used in this experiment, with the exception of the Spalding T0 samples, had $\mathrm{pH}_{\mathrm{CaCl} 2}$ values $<6$, 
it can be assumed that differences in soil $\mathrm{pH}$ between sampling times had a relatively minor impact on lability. This was confirmed by linear regression of the mean control soil $\mathrm{pH}$ for each sampling period and soil type versus the slopes of graphs of labile $\mathrm{Zn}$ vs. total $\mathrm{Zn}$ (not shown) $\left(\mathrm{R}^{2}=0.04, \mathrm{p}>0.05\right)$.

For all four soils the labile $\mathrm{Zn}$ expressed as a percentage of total added $\mathrm{Zn}$ at T0 varied from $70-90 \%$ for most $\mathrm{Zn}$ treatments, although in the low $\mathrm{Zn}$ treatments $(<100 \mathrm{mg}$ $\mathrm{kg}^{-1}$ total added $\mathrm{Zn}$ ) at Kingaroy this value was as low as $40 \%$ (Figure 1).

Theoretically, it can be assumed that upon addition of the $\mathrm{Zn}$ salts (i.e. at the true time zero) the added $\mathrm{Zn}$ would have been $100 \%$ labile. Thus, by the time the T0 samples had been spiked, mixed, leached, dried and sieved ready for analysis (i.e. 6 days), up to 60 $\%$ of the added $\mathrm{Zn}$ had already been fixed by the soil. Nevertheless, the leaching step, which was the major cause of this delay, was considered an essential part of the experiment, as the samples were also used to measure ecotoxicity with the lux biosensor. Leaching not only removes much of the added counter ion and reduces the ionic strength of the soil solution towards its natural state, it also replenishes the system with calcium and potassium (Stevens et al., 2003; Fait et al., 2006). Leached samples are thus more representative of field conditions (where leaching occurs naturally), and less likely to confound ecotoxicity data by elevated salt concentrations contributing to the adverse effects reflected in $\mathrm{EC}_{x}$ values (Stevens et al., 2003; McLaughlin et al., 2004).

\section{Zn buffer capacity - relationship between $E_{e}$ values and solution $\mathrm{Zn}$}

Sorption curves, with the isotopically exchangeable $\mathrm{Zn}$ fraction $\left(\mathrm{E}_{\mathrm{e}}\right.$-value) plotted against the solution $\mathrm{Zn}$ fraction, are presented in Figure 2. Linear regression analysis of the log-log transformed data indicated a small but significant time-dependent decrease 
in the quantity of isotopically exchangeable Zn for all soils except Dutson Downs (Table 4). Decreases in $\mathrm{E}_{\mathrm{e}}$ over time for corresponding quantities of solution $\mathrm{Zn}$ indicates a net movement of $\mathrm{Zn}$ from the labile exchangeable pool to the fixed (nonlabile) pool, thus providing further evidence for $\mathrm{Zn}$ ageing.

Generally, the shape of a sorption curve is considered to indicate the bonding strength or affinity of the sorbate for the soil surface (Tom-Petersen et al., 2004). In the curves shown in Figure 2 steeper slopes reveal greater partitioning of $\mathrm{Zn}$ to the solid phase, and the slopes decrease in the order Spalding $>$ Kingaroy $>$ Dookie $>$ Dutson Downs. For a given quantity of surface exchangeable $\mathrm{Zn}$, the soils with greater slopes maintain correspondingly lower concentrations of solution Zn. Likely characteristics accounting for these differences in $\mathrm{Zn}$ retention include soil $\mathrm{pH}$, clay content, type of clay mineral present, and surface charge characteristics (see Tiller et al., 1984; Barrow, 1987; Sauvé

et al., 2000; Harter and Naidu 2001; Degryse et al., 2003). Notably, both the pH and CEC of the different soil types decreased in the same soil order as that specified above, whilst Kingaroy, Spalding and Dookie also had higher clay contents than the Dutson Downs soil, and Kingaroy contained a much higher proportion of free Fe-oxide minerals (indicated by high citrate-dithionite extractable Fe) than the other soil types (Table 1).

\section{Zn toxicity to E. coli $\mathrm{HB101}$ pUCD607}

The $\mathrm{EC}_{50}$ values for each combination of soil and sampling time and their $95 \%$ CIs are presented in Figure 3. Overall, there was no consistent temporal trend in toxicity. This is contrary to the hypothesis that $\mathrm{Zn}$ ageing processes would give rise to higher total $\mathrm{Zn}$ $\mathrm{EC}_{50}$ values for the aged samples than for the freshly spiked samples, due to reductions 
in the extractable/bioavailable/labile $\mathrm{Zn}$ fraction caused by increasing fixation over time. Standard error of the difference testing (Sprague and Fogels, 1977) confirmed that there was no significant difference between the $\mathrm{T} 0$ and $\mathrm{T} 2 \mathrm{EC}_{50}$ values for Dookie and Spalding, whilst the significant difference between the Kingaroy T0 and $\mathrm{T}_{2} \mathrm{EC}_{50}$ values signalled by non-overlapping CIs (Nelson, 1989) indicated a decrease in $\mathrm{EC}_{50}$ rather than an increase.

The lux biosensor responds to the bioavailable $\mathrm{Zn}$ in the solution it is exposed to (Tandy et al., 2005) which is largely dependent on the Zn speciation (Nolan et al., 2003). In this experiment, the lack of a clear pattern in water-extractable $\mathrm{Zn} \mathrm{EC}_{50}$ values over time (results not shown) suggests there was no systematic change in the speciation of the soil-water extracts as a result of ageing. However, differences in the speciation of the test solutions due to variations in $\mathrm{pH}, \mathrm{DOC}$, and various soil-derived ligands, together with the effects of competing co-ions on cell uptake, may well account for some of the variation in the calculated $\mathrm{EC}_{50}$ values. In fact, it is possible that the reliance on soil-water extracts for exposure of the biosensor may have impeded the detection of ageing effects, because any differences in extractability due to differences in sample $\mathrm{pH}$ or other soil properties would also be reflected in the bioassay results.

Across all soil types, significantly higher DOC concentrations were recorded for T0 control samples than for T0 treatment samples (t-test, $\mathrm{p}<0.01$ ). This was probably due to the increased salt concentrations in the freshly spiked samples. The differences between control and treatment samples diminished over the course of the experiment and were not significant for $\mathrm{T} 1$ and $\mathrm{T} 2$ samples (t-test, $\mathrm{p}>0.05$ ), probably due to decreasing soluble salt contents as a result of ongoing leaching. Given that $\mathrm{Zn}$ in solution may bind to DOC and hence become less bioavailable, the finding of lower 
DOC in the freshly spiked samples than in the aged samples is important, showing that ageing effects had not been masked by decreases in DOC over time. On the other hand, differences in sample $\mathrm{pH}$ may well have played a role in obscuring any ageing effects, as a simple linear regression through the lux biosensor (total added $\mathrm{Zn}$ ) $\mathrm{EC}_{50}$ values for all soil types and sampling times was highly significant $(\mathrm{p}<0.01)$ (Figure 4) with soil $\mathrm{pH}_{\mathrm{CaCl} 2}$ alone explaining $79 \%$ of the variation in $\mathrm{Zn}$ toxicity to the lux biosensor. In any case, these results indicate the potential drawbacks of using blanket regulatory limits for all soil types based on total metal contents without taking into consideration the modulating effects of key soil properties on $\mathrm{Zn}$ toxicity.

Previous studies using microbial endpoints to investigate $\mathrm{Zn}$ ageing are relatively limited and must also be interpreted with respect to a range of potentially confounding factors affecting both metal partitioning and ecotoxicity over time. Indeed, Lombi et al. (2007) noted several examples (e.g. Doelman and Haanstra, 1984; Kelly et al., 1999; Smolders et al., 2003) where apparent evidence of decreasing toxicity of added Zn over time may also have been affected by adaptation of the soil microbial community (Rusk et al., 2004; Fait et al., 2006) and/or by leaching of excess salts (McLaughlin et al., 2004). Taking into account the published results together with the present experiment, it must be concluded that the significance of $\mathrm{Zn}$ ageing as a factor affecting ecotoxicity remains uncertain. However, this is not to say that ageing does not play a role. Except in high $\mathrm{pH}$ soils, ageing processes are only expected to produce small changes in metal lability/toxicity over relatively long periods of time (Tye et al., 2003), and natural biological variability combined with changes in soil parameters affecting metal partitioning could make detection of ageing processes using biological endpoints quite difficult (Lombi et al., 2007). In situ ecotoxicity monitoring using fibre optic linked 
membrane bound biosensor probes (Paton et al., 1997; Nivens et al., 2004) and/or experiments facilitating the direct extraction of soil porewater for testing may prove to be superior in this respect.

In our study, significant reductions in Zn lability between spiking and after leaching/drying (a period of only 6 days) indicates that soil treatment after spiking using soluble metal salts (prior to assessment of ecotoxicity) is crucial in defining metal bioavailability and hence ecotoxicity thresholds. It also strengthens the argument that metal toxicity and availability assessed in soils spiked with soluble metal salts without a post-spiking leaching and ageing treatment are grossly overestimated (Stevens et al., 2003; Smolders et al., 2004).

\section{CONCLUSIONS}

The identification of ageing under field conditions is an important part of establishing the practical significance of metal fixation, with effects being more difficult to detect due to the increased variability over laboratory conditions, but correspondingly more meaningful when apparent. In this experiment, the expected decrease in $\mathrm{CaCl}_{2}$ extractable $\mathrm{Zn}$ over time was not detected. This was attributed to the strong effect of soil $\mathrm{pH}$ on this measurement, and the finding that $\mathrm{pH}$ varied over time at most sites. As most of the soils were acidic, it is also possible that fixation was not particularly extensive and hence difficult to detect by this method. Measurements using radioisotope dilution $\left(E_{a}\right.$ and $E_{e}$ values) demonstrated a significant effect of time on Zn lability, and indicated that most of the fixation proceeded quite rapidly after $\mathrm{Zn}$ spiking, with a considerable decrease in lability occurring even before Zn lability and ecotoxicity inthe freshly spiked samples could be determined (i.e. in the 6 days after spiking during which soils were leached and dried). The E.coli HB101 pUCD607 lux biosensor was used as a 
microbial toxicity assay (unaffected by adaptation) to assess whether changes in lability over time would be detectable by changes in toxicity, but produced no evidence to suggest that $\mathrm{Zn}$ ageing processes had led to decreased bioavailability of $\mathrm{Zn}$ between 6 days and 2 years. On the other hand, Zn sorption and bioavailability were shown to vary according to soil type on the basis of both chemical and biosensor results. This finding indicates the importance of soil properties in modulating the toxicity of added soil Zn. Further work is needed to assess the importance of long-term ageing in terms of bioavailability and toxicity, and whether or not this process is significant enough to warrant inclusion in risk assessment, predictive models and the setting of safe limits for $\mathrm{Zn}$ in the environment.

Acknowledgements - E. Donner would like to thank the Commonwealth Scholarships Commission in the UK for PhD funding, and CSIRO Land and Water (Urrbrae, SA) for hosting the visit during which this work was undertaken. She is also grateful to Dr. F. Zhao, Prof. S. McGrath, Dr. G. Paton, Dr. E. Lombi, and Dr. R. Hamon for helpful discussions. The National Biosolids Research Program (NBRP) gratefully acknowledges its numerous financial supporters. The authors would like to acknowledge G. Barry, M. Bell, M. Boomsma, D. Nash, N. Penney, D. Pritchard, J. Stokes, and M. Whatmuff for leading the various state components of the NBRP; C. Baldock, G. Cozens, A. Daly, A. Pastuhova, G. Pollard, M. Smart, B. Tomczak, and C. Fiebiger for technical assistance. 


\section{REFERENCES}

1. Alloway, B.J., 2003. Zinc in soils and crop nutrition. International Zinc Association, Brussels. www.zinc-crops.org

2. Armour, J.D., Ritchie, G.S.P., Robson, A.D., 1989. Changes with time in the availability of soil applied zinc to navy beans and in the chemical extraction of zinc from soils. Australian Journal of Soil Research 27, 699 - 710.

3. Barnes, M., Correll, R., Stevens, D., 2003. A simple spreadsheet for estimating loweffect concentrations and associated confidence intervals with logistic dose response curves. Conference paper presented at Society of Environmental Toxicology and Chemistry (SETAC) Asia/Pacific- Australasian Society for Ecotoxicology (ASE) Meeting: Solutions to Pollution 2003, Christchurch, New Zealand, 28 September-1 October 2003.

4. Barr, D.R, 1969. Using confidence intervals to test hypotheses. Journal of Quality Technology 1, $256-258$.

5. Barrow, N.J., 1978. The description of phosphate adsorption curves. Journal of Soil Science 29, $447-462$.

6. Barrow, N.J., 1986. Testing a mechanistic model. IV. Describing the effects of $\mathrm{pH}$ on zinc retention by soils. Journal of Soil Science 37, 295 - 302.

7. Barrow, N.J., 1987. Reactions with variable charge soils. Martinus Nijhoff Publishers, Dordrecht. 
8. Blakemore, L. C., Searle, P. L., Daly, B. K., 1987. Methods for chemical analysis of soils. New Zealand Soil Bureau Scientific Report 80. New Zealand Soil Bureau. Department of Scientific and Industrial Research, Lower Hutt, New Zealand.

9. Boawn, L.C., Viets, F.G., Crawford, C.L., Nelson, J.L., 1960. Effect of nitrogen carrier, nitrogen rate, zinc rate, and soil $\mathrm{pH}$ on zinc uptake by sorghum, potatoes, and sugar beets. Soil Science 90, $329-337$.

10. Broos, K., Uyttebroek, M., Mertens, J., Smolders, E., 2004. A survey of symbiotic nitrogen fixation by white clover grown on metal contaminated soils. Soil Biology and Biochemistry 36, $633-640$.

11. Broos, K., Warne, M.St.J., Heemsbergen, D.A., Stevens, D., Barnes, M.B., Correll, R.L., McLaughlin, M.J., 2007. Soil factors controlling the toxicity of copper and zinc to microbial processes in Australian soils. Environmental Toxicology and Chemistry 26(4), $583-590$.

12. Brown, A.L., Krantz, B.A., Martin, P.E. (1964). The residual effect of zinc applied to soils. Soil Science Society of America Proceedings 28, 236 - 238.

13. Brown, P.H., Cakmak, I., Zhang, Q., 1993. Form and function of zinc in plants, in: Robson, A.D. (Ed.), Zinc in Soils and Plants. Kluwer Academic Publishers, Dordrecht, pp. $90-106$. 
14. Chaudri, A.M., McGrath, S.P., Giller, K.E., 1992. Survival of the indigenous population of Rhizobium leguminosarum biovar trifolii in soil spiked with $\mathrm{Cd}, \mathrm{Zn}, \mathrm{Cu}$ and Ni salts. Soil Biology and Biochemistry, 24, 625 - 632 .

15. Degryse, F., Broos, K., Smolders, E., Merckx, R., 2003. Soil solution concentration of $\mathrm{Cd}$ and $\mathrm{Zn}$ can be predicted with a $\mathrm{CaCl}_{2}$ soil extract. European Journal of Soil Science 54, $149-157$.

16. Degryse, F., Buekers, J., Smolders, E., 2004. Radio-labile cadmium and zinc in soils as affected by $\mathrm{pH}$ and source of contamination. European Journal of Soil Science 55, $113-121$.

17. Doelman, P., Haanstra, L., 1984. Short-term and long-term effects of cadmium, chromium, copper, nickel, lead, and zinc on soil microbial respiration in relation to abiotic soil factors. Plant and Soil. 79, 317-327.

18. Fait, G., Broos, K., Zrna, S., Lombi, E., Hamon, R., 2006. Tolerance of nitrifying bacteria to copper and nickel. Environmental Toxicology and Chemistry 25, $2000-$ 2005 .

19. Follett, R.H., Lindsay, W.L., 1971. Changes in DTPA-extractable zinc, iron, manganese, and copper in soils following fertilization. Soil Science Society of America Proceedings 35, $600-602$. 
20. Hamon, R.E., McLaughlin, M.J., Cozens, G., 2002a. Mechanisms of attenuation of metal availability in in situ remediation treatments. Environmental Science and Technology 36, $3991-3996$.

Hamon, R.E., Bertrand, I., and McLaughlin, M.J., 2002b. Use and abuse of isotopic exchange data in soil chemistry. Australian Journal of Soil Research 40, 1371 - 1381.

21. Harter, R.D., Naidu, R., 2001. An assessment of environmental and solution parameter impact on trace-metal sorption by soils. Soil Science Society of America Journal 65, $597-612$.

22. Impellitteri, C.A., Allen, H.E., Yin, Y., You, S-J., Saxe, J.K., 2001. Soil properties controlling metal partitioning, in: Selim, H.M., Sparks, D. (Eds.), Heavy metals release in soils. Lewis Publishers, pp. $149-165$.

23. Isbell, R. F., 1996. The Australian Soil Classification. CSIRO Publishing, Collingwood, Victoria.

24. Ivask, A., Francois, M., Kahru, A., Dubourguier, H-C., Virta, M., Douay, F., 2004. Recombinant luminescent bacterial sensors for the measurement of bioavailability of cadmium and lead in soils polluted by metal smelters. Chemosphere 55, $147-156$.

25. Kelly, J.J., Haggblom, M., Tate, R.L., 1999. Changes in soil microbial communities over time resulting from one time application of zinc: a laboratory microcosm study. Soil Biology and Biochemistry 31, $1455-1465$. 
26. Lo, N.C.H., 1994. Level of significance and power of two commonly used procedures for comparing mean values based on confidence intervals. CalCOFI Reports $35,246-253$.

27. Lombi, E., Stevens, D.P., Hamon, R.E., McLaughlin, M.J., 2007. Biological assessment of natural attenuation of metals in soil, in: Hamon, R., McLaughlin, M., Lombi, E. (Eds.), Natural attenuation of trace element availability in soils. SETAC Press, Florida, pp. $41-55$.

28. Ma, Y.B., Uren, N.C., 1997a. The effects of temperature, time and cycles of drying and rewetting on the extractability of zinc added to a calcareous soil. Geoderma 75, 89 97.

29. Ma, Y.B., Uren, N.C., 1997b. The fate and transformations of zinc added to soils. Australian Journal of Soil Research 35, 727 - 738.

30. McLaughlin, M.J., Hamon, R.E., McLaren, R.G., Speir, T.W., Rogers, S.L., 2000. Review: A bioavailability-based rationale for controlling metal and metalloid contamination of agricultural land in Australia and New Zealand. Australian Journal of Soil Research 38, $1037-86$.

31. McLaughlin, M.J., Hamon, R., Lombi, E., Smolders, E., 2004. Metal ecotoxicity protocols in soil - rubbing salt into the wounds. SETAC Globe, Learned Discourse 5, $51-52$ 
32. McLaughlin, M.J., Whatmuff, M., Warne, M., Heemsbergen, D., Barry, G., Bell, M., Nask, D., Pritchard., 2006. Environmental Chemistry 3, 428 - 432.

33. Nakhone, L.N., Young, S.D., 1993. The significance of (radio-) labile cadmium pools in soil. Environmental Pollution 82, $73-77$.

34. Nelson LS, 1989. Evaluating overlapping confidence intervals. Journal of Quality Technology, 21, 140-141.

35. Nivens, D.E., McKnight, T.E., Moser, S.A., Osbourn, S.J., Simpson, M.L., and Sayler, G.S., 2004. Bioluminescent bioreporter integrated circuits: potentially small, rugged and inexpensive whole-cell biosensors for remote environmental monitoring. Journal of Applied Microbiology 96, 33 - 46.

36. Nolan, A.L., Lombi, E., McLaughlin, M.J., 2003. Metal bioaccumulation and toxicity in soils - why bother with speciation? Australian Journal of Chemistry 56, 77 91.

37. Paton, G.I., Rattray, E.A.S., Campbell, C.D., Cresser, M.S., Glover, L.A., Meeussen, J.C.L., Killham, K., 1997. Use of genetically modified microbial biosensors for soil ecotoxicity testing, in: Pankhurst, C.E., Doube, B.M., Gupta, V.V.S.R. (Eds.), Biological Indicators of Soil Health. CAB International, New York, pp. $397-418$.

38. Rayment, G. E., Higginson, F. R., 1992. Australian laboratory handbook of soil and water chemical methods. Inkata Press, Melbourne. 
39. Rusk, J. A., Hamon, R. E., Stevens, D. P., McLaughlin, M. J. (2004). Adaptation of soil biological nitrification to heavy metals. Environmental Science and Technology 38, $3092-3097$.

40. Sauvé, S., Hendershot, W., Allen, H.E., 2000. Solid-solution partitioning of metals in contaminated soils: Dependence on $\mathrm{pH}$, total metal burden, and organic matter. Environmental Science and Technology 34, 1125 - 1131.

41. Sherrod, L.A., Dunn, G., Peterson, G.A., Kolberg, R.L., 2002. Inorganic carbon analysis by modified pressure-calcimeter method. Soil Science Society of America Journal 66, $299-305$.

42. Smolders, K., McGrath, S., Lombi. E., Karman, C.C., Bernhard, R., Cools, D., van der Brande, K., van Os, B., Walrave, N., 2003. Comparison of toxicity of zinc for soil microbial processes between laboratory-contaminated and polluted field soils. Environmental Toxicology and Chemistry 22, $2592-2598$.

43. Smolders, E., Buekers, J., Oliver, I., McLaughlin, M.J., 2004. Soil properties affecting toxicity of zinc to soil microbial properties in laboratory-spiked and fieldcontaminated soils. Environmental Toxicology and Chemistry 23, 2633 - 2640.

44. Smolders, E., Degryse, F., 2007. Fixation of cadmium and zinc in soils: Implications for risk assessment, in: Hamon, R., McLaughlin, M., Lombi, E. (Eds.) Natural attenuation of trace element availability in soils. SETAC Press, Florida, pp. 157 - 171. 
45. Sparks, D.L., 1998. Kinetics of soil chemical phenomena: Future direction, in: Future prospects for soil chemistry. SSSA Special Publication No. 55, pp. $81-103$.

46. Sposito, G., 1984. The surface chemistry of soils. Oxford University Press, New York.

47. Sprague JB, and Fogels A, 1977. Watch the Y in Bioassay. Proc. 3rd Aquatic Toxicity Workshop, Halifax, NS, Nov. 2-3, 1976. Environmental Protection Service Technical Report No. EPS-5-AR-77-1, Halifax, Canada.

48. Stevens, D.P., McLaughlin, M.J., Heinrich, T., 2003. Determining toxicity of lead and zinc runoff in soils: salinity effects on metal partitioning and on phytotoxicity. Environmental Toxicology and Chemistry 22, 3017 - 3024.

49. Tandy, S., Barbosa, V., Tye, A., Preston, S., Paton, G., Zhang, H., McGrath, S., 2005. Comparison of different microbial bioassays to assess metal-contaminated soils. Environmental Toxicology and Chemistry 24, 530 - 536.

50. Tiller, K.G., Gerth, J., Brümmer, G., 1984. The relative affinities of Cd, Ni and Zn for different soil clay fractions and goethite. Geoderma 34, 17 - 35 .

51. Tom-Petersen, A., Hansen, H.C.B., Nybroe, O., 2004. Time and moisture effects on total and bioavailable copper in soil water extracts. Journal of Environmental Quality $33,505-512$. 
52. Tye, A.M., Young, S.D., Crout, N.M.J., Zhang, H., Preston, S., Barbosa-Jefferson, V.L, Davison, W., McGrath, S.P., Paton, G.I., Kilham, K., Resende, L., 2003.

Predicting the activity of $\mathrm{Cd}^{2+}$ and $\mathrm{Zn}^{2+}$ in soil pore water from the radio-labile metal fraction. Geochimica et Cosmochimica Acta 67, 375 - 385 .

53. Warne, M.St.J., Heemsbergen, D., Stevens, D., McLaughlin, M., Cozens, G., Whatmuff, M., Broos, K., Barry, G., Bell, M., Nash, D., Pritchard,. D., Penney, N., 2008. Modelling the toxicity of copper and zinc salts to wheat in 14 soils.

Environmental Toxicology and Chemistry 27(4), 786 - 792.

54. Warne, M.St.J., Heemsbergen, D.A., McLaughlin, M.J., Bell, M., Broos, K., Whatmuff, M., Barry, G., Nash, D., Pritchard, D., and Penney, N., in press. Models for the field-based toxicity of copper and zinc salts to wheat in eleven Australian soils and comparison of laboratory-based models. Environmental Pollution 156(3), 707 - 714.

55. Young, S.D., Tye, A., Carstensen, L., Resende, L, Crout, N., 2000. Methods for determining labile cadmium and zinc in soil. European Journal of Soil Science 51, 129 $-136$. 


\section{FIGURE LEGENDS}

Figure 1: Percentage of labile added $\mathrm{Zn}$ presented as a function of total added $\mathrm{Zn}$.

Figure 2: Isotopically exchangeable $\mathrm{Zn}\left(\mathrm{E}_{\mathrm{e}}\right)$ as a function of the solution $\mathrm{Zn}$ concentration.

Figure 3: Lux biosensor $\mathrm{EC}_{50}$ values calculated for each soil type and time period on the basis of total added $\mathrm{Zn}$ concentration. The error bars represent the $95 \%$ confidence intervals.

Figure 4: Lux biosensor $\mathrm{EC}_{50}$ values (total added $\mathrm{Zn}$ ) for all soils and sampling times as a function of soil $\mathrm{pH}$. The soil $\mathrm{pH}$ values are the mean $\mathrm{pH}\left(0.01 \mathrm{MCaCl}_{2}\right)$ for each bioassay. $\mathrm{X}$ error bars are the $\mathrm{SE}$ of the mean for the soil $\mathrm{pH}$. Y error bars indicate the $95 \%$ confidence intervals for the measured $\mathrm{EC}_{50}$ values. 


\section{TABLE LEGENDS}

Table 1: Selected chemical and physical properties of the 4 experimental soils, expressed on an oven dry $\left(105^{\circ} \mathrm{C}\right)$ basis. Where applicable, standard errors are given in brackets $(\mathrm{n}=4$ for total $\mathrm{Zn}$ and $\mathrm{Fe} ; \mathrm{n}=3$ for $\mathrm{pH}$ measurements, $\mathrm{EC}$ and Fe extractions. Other values presented (CEC, exchangeable cations, and particle size) are the means of duplicate samples.

Table 2: Slopes of linear regression lines and significance testing results for concentrations of $\mathrm{CaCl}_{2}$-extractable added $\mathrm{Zn}$ against total added $\mathrm{Zn}$ at each time period. Intercepts were constrained to the origin. Significant differences in slope between T0 (freshly spiked), T1 (after $1^{\text {st }}$ harvest) and T2 (after $2^{\text {nd }}$ harvest) data for each soil type are indicated by differing superscripts.

Table 3: Slopes of linear regression lines for labile added $\mathrm{Zn}$ against total added $\mathrm{Zn}$. Intercepts were constrained to the origin. Significant differences in slope between $\mathrm{T} 0, \mathrm{~T} 1$ and $\mathrm{T} 2$ data for each site are indicated by different superscripts.

Table 4: Intercepts of linear regression equations derived from log-log transformed data from Figure 2 (labile exchangeable Zn against solution Zn). Significant differences in intercept between T0, T1 and T2 data for each site are indicated by different superscripts. 
Table 1: Selected chemical and physical properties of the 4 experimental soils, expressed on an oven dry $\left(105^{\circ} \mathrm{C}\right)$ basis. Where applicable, standard errors are given in brackets $(\mathrm{n}=4$ for total $\mathrm{Zn}$ and $\mathrm{Fe} ; \mathrm{n}=3$ for $\mathrm{pH}$ measurements, $\mathrm{EC}$ and Fe extractions. Other values presented (CEC, exchangeable cations, and particle size) are the means of duplicate samples.

\begin{tabular}{|c|c|c|c|c|}
\hline & Dookie & Dutson Downs & Kingaroy & Spalding \\
\hline Soil type ${ }^{a}$ & Dermosol & Podosol & Ferrosol & Chromosol \\
\hline $\mathrm{pH}\left(0.01 \mathrm{M} \mathrm{CaCl}_{2}\right)$ & $5.0(0.01)$ & $3.9(0.01)$ & $5.3(0.02)$ & $6.6(0.04)$ \\
\hline Electrical Conductivity $\left(\mathrm{dS} \mathrm{m}^{-1}\right)$ & $0.1(0.003)$ & $0.08(0.001)$ & $0.06(0.003)$ & $0.08(0.003)$ \\
\hline Organic C (\%) & 2.0 & 5.6 & 1.8 & 1.9 \\
\hline $\operatorname{CEC}\left(\mathrm{cmol}^{+} \mathrm{kg}^{-1}\right)$ & 10.7 & 7.9 & 16.9 & 17.7 \\
\hline \multirow{2}{*}{$\begin{array}{l}\text { Exchangeable cations } \\
\left(\mathrm{cmol}^{+} \mathrm{kg}^{-1}\right)\end{array}$} & Ca: 5.8 & Ca: 3.2 & Ca: 8.9 & Ca: 11.0 \\
\hline & Mg: 1.1 & Mg: 0.9 & Mg: 2.1 & $\mathrm{Mg}: 3.6$ \\
\hline \multirow{5}{*}{ Particle size distribution } & Na: 0.1 & Na: 0.1 & Na: 0.1 & Na: 0.1 \\
\hline & $\mathrm{K}: 1.2$ & $\mathrm{~K}: 0.2$ & $\mathrm{~K}: 1.0$ & $\mathrm{~K}: 2.2$ \\
\hline & $22 \%$ clay & $4 \%$ clay & $32 \%$ clay & $23 \%$ clay \\
\hline & $21 \%$ silt & $5 \%$ silt & $39 \%$ silt & $35 \%$ silt \\
\hline & $57 \%$ sand & $91 \%$ sand & $29 \%$ sand & $42 \%$ sand \\
\hline Total Fe (\%) & $3.3(0.10)$ & $0.1(0.00)$ & $14.5(0.06)$ & $3.0(0.06)$ \\
\hline Citrate-dithionite $\mathrm{Fe}(\%)$ & $2.1(0.02)$ & $0.1(0.00)$ & $10.2(0.17)$ & $1.5(0.01)$ \\
\hline Ammonium oxalate $\mathrm{Fe}(\%)$ & $0.4(0.00)$ & $0.1(0.00)$ & $0.4(0.02)$ & $0.1(0.00)$ \\
\hline $\begin{array}{l}\text { Total } \mathrm{Zn} \text { in control soil } \\
\left(\mathrm{mg} \mathrm{kg}^{-1}\right)\end{array}$ & $25.0(0.48)$ & $11.0(0.07)$ & $89.4(0.52)$ & $48.6(0.72)$ \\
\hline \multicolumn{5}{|l|}{$\begin{array}{l}\text { Range of total } \mathrm{Zn} \text { concentrations } \\
\text { determined }\left(\mathrm{mg} \mathrm{kg}^{-1}\right)\end{array}$} \\
\hline T0 (freshly spiked) & $25-1550$ & $10-900$ & $90-2350$ & $50-2550$ \\
\hline $\mathrm{T} 1$ (after $1^{\text {st }}$ harvest) & $25-1950$ & $15-1300$ & $95-1250$ & $60-4250$ \\
\hline $\mathrm{T} 2$ (after $2^{\text {nd }}$ harvest) & $25-900$ & $10-600$ & $90-1050$ & $60-3650$ \\
\hline
\end{tabular}

${ }^{\mathrm{a}}$ Australian Soil Classification System (Isbell, 1996) 
Table 2: Slopes of linear regression lines and significance testing results for concentrations of $\mathrm{CaCl}_{2}$-extractable added $\mathrm{Zn}$ against total added $\mathrm{Zn}$ at each time period. Intercepts were constrained to the origin. Significant differences in slope between T0 (freshly spiked), T1 (after $1^{\text {st }}$ harvest) and T2 (after $2^{\text {nd }}$ harvest) data for each soil type are indicated by differing superscripts.

\begin{tabular}{lllll}
\hline & Dookie & Dutson Downs & Kingaroy & Spalding \\
\hline T0 & $0.36^{\mathrm{a}}$ & $0.53^{\mathrm{a}}$ & $0.33^{\mathrm{a}}$ & $0.15^{\mathrm{a}}$ \\
$\mathrm{T} 1$ & $0.44^{\mathrm{b}}$ & $0.55^{\mathrm{a}}$ & $0.29^{\mathrm{a}}$ & $0.27^{\mathrm{b}}$ \\
$\mathrm{T} 2$ & $0.37^{\mathrm{a}}$ & $0.46^{\mathrm{b}}$ & $0.30^{\mathrm{a}}$ & $0.25^{\mathrm{b}}$ \\
\hline
\end{tabular}


Table 3: Slopes of linear regression lines for labile added Zn against total added $\mathrm{Zn}$. Intercepts were constrained to the origin. Significant differences in slope between $\mathrm{T} 0, \mathrm{~T} 1$ and $\mathrm{T} 2$ data for each site are indicated by different superscripts.

\begin{tabular}{lllll}
\hline & Dookie & Dutson Downs & Kingaroy & Spalding \\
\hline T0 & $0.82^{\mathrm{a}}$ & $0.77^{\mathrm{a}}$ & $0.94^{\mathrm{a}}$ & $0.81^{\mathrm{a}}$ \\
$\mathrm{T} 1$ & $0.81^{\mathrm{a}}$ & $0.72^{\mathrm{b}}$ & $0.76^{\mathrm{b}}$ & $0.72^{\mathrm{b}}$ \\
$\mathrm{T} 2$ & $0.74^{\mathrm{b}}$ & $0.76^{\mathrm{a}}$ & $0.76^{\mathrm{b}}$ & $0.73^{\mathrm{b}}$ \\
\hline
\end{tabular}


Table 4: Intercepts of linear regression equations derived from log-log transformed data from Figure 2 (labile exchangeable $\mathrm{Zn}$ against solution $\mathrm{Zn}$ ). Significant differences in intercept between T0, T1 and T2 data for each site are indicated by different superscripts.

\begin{tabular}{lllll}
\hline & Dookie & Dutson Downs & Kingaroy & Spalding \\
\hline $\mathrm{T} 0$ & $1.03^{\mathrm{a}}$ & $0.24^{\mathrm{a}}$ & $1.46^{\mathrm{a}}$ & $1.92^{\mathrm{a}}$ \\
$\mathrm{T} 1$ & $0.91^{\mathrm{b}}$ & $0.37^{\mathrm{a}, \mathrm{b}}$ & $1.40^{\mathrm{a}, \mathrm{b}}$ & $1.60^{\mathrm{b}}$ \\
$\mathrm{T} 2$ & $0.83^{\mathrm{b}}$ & $0.41^{\mathrm{b}}$ & $1.34^{\mathrm{b}}$ & $1.63^{\mathrm{b}}$ \\
\hline
\end{tabular}

